\title{
Fungal bezoar in an immunocompetent patient: a rare complication of forgotten double J stent
}

\author{
Ashish Sharma, Gaurav Garg, Deepanshu Sharma, Manmeet Singh
}

Urology, King George's Medical University, Lucknow, Uttar Pradesh, India

Correspondence to Dr Gaurav Garg, gougarg@gmail.com

Accepted 6 August 2018

\section{DESCRIPTION}

A 38-year-old man presented with intermittent right flank pain, dysuria, passage of turbid urine and low-grade fever for the last 1 year. He revealed a history of right-sided laparoscopic Anderson-Hynes dismembered pyeloplasty with double J (DJ) stenting performed for right pelviureteric junction obstruction 5 years back at other centre. The discharge card given to the patient advised for DJ stent removal, but the patient was lost to follow-up and never underwent DJ removal. His medical history was unremarkable for diabetes, HIV or steroid intake. On physical examination there was tenderness present in right flank on deep palpation. Blood serum chemistries revealed mildly deranged renal function tests (blood urea nitrogen $56 \mathrm{mg} / \mathrm{dL}$; serum creatinine $1.5 \mathrm{mg} / \mathrm{dL}$ ) with normal random blood sugar $(92 \mathrm{mg} / \mathrm{dL})$ and liver function tests. Urine analysis showed 40-50 pus cells/high power field (HPF), 20 red blood cells/HPF and presence of fungal hyphae and spores. Urine culture revealed $>10^{5}$ colony counts of Candida albicans per $\mathrm{mL}$.

On evaluation with kidney, ureter and bladder $\mathrm{X}$-ray there was presence of right DJ stent without encrustation and radiopaque shadow in left renal region (figure 1A). Ultrasonography of abdomen revealed severely dilated right kidney showing multiple hyperechoic rounded lesions $(15-25 \mathrm{~mm})$ with a DJ stent in situ and left renal pelvic calculus $(21 \mathrm{~mm})$ (figure 1B). Further evaluation with contrast enhanced CT scan of abdomen showed presence of isodense non-enhancing multiple

A

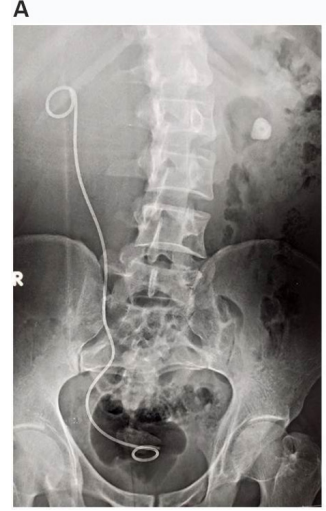

B

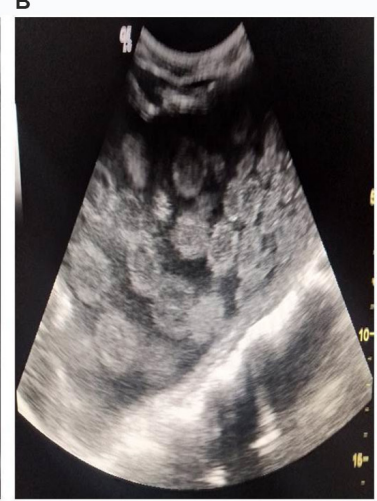

Figure 1 (A) Kidney, ureter and bladder (KUB) X-ray image showing presence of right double J (DJ) stent without encrustation and radiopaque shadow in left renal region. (B) Ultrasonography image showing severely dilated right kidney with multiple hyperechoic rounded lesions.
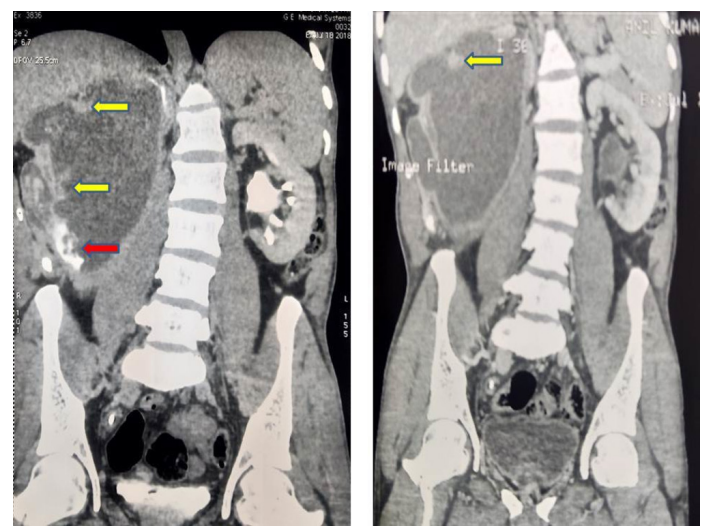

Figure 2 Contrast enhanced CT scan of abdomen showing presence of isodense non-enhancing multiple intraluminal filling defects with tiny peripheral calcifications in massively dilated right renal pelvis (yellow arrow-multiple filling defects near renal pelvic wall, red arrow-filling defects with tiny calcifications).

intraluminal filling defects with tiny peripheral calcifications in massively dilated right renal pelvis (suggestive of fungal balls) (figure 2). The patient underwent ureteric stent removal followed by placement of right-sided percutaneous nephrostomy (PCN). It initially drained about $500 \mathrm{~mL}$ turbid urine mixed with debris and flakes in first 24 hours followed by minimal output. He received oral fluconazole $(400 \mathrm{mg})$ once daily treatment for 2 weeks with gravity-dependent low-pressure intrapelvic instillation of deoxycholate amphotericin B $(10 \mathrm{mg} / \mathrm{L}$ of $5 \%$ dextrose in water $)$ via PCN. Further evaluation with Tc $99 \mathrm{~m}$ renal scan revealed non-functioning right kidney. After proper counselling and consent, he underwent right nephrectomy followed by left percutaneous nephrolithotomy. At 3 months of follow-up, he was doing well with no residual stone or hydronephrosis on ultrasound abdomen on left side.

The fungal infections of upper urinary tract are relatively uncommon entity, and fungal bezoar is particularly rare. ${ }^{1}$ In literature, only handful cases of renal or ureteric fungal bezoar are reported and mostly in immunocompromised individuals. These fungal bezoars are usually formed by localised clusters of fungal mycelia without adjacent tissue invasion and sometimes it may become large enough to cause obstructive uropathy. The predisposing risk factors include diabetes, prolonged bladder catheterisation or retained foreign body, malignancy and prolonged antibiotic administration. ${ }^{2}$ Untreated fungal infections can lead to urinary tract obstruction, urosepsis, hydronephrosis and secondary 


\section{Learning points}

- Fungal bezoar is a rare upper urinary tract infection mostly seen in immunocompromised individuals.

- In rare cases, fungal bezoar may develop in immune competent individuals as a complication of forgotten double J stent.

- The urinary tract obstruction, urosepsis, hydronephrosis and secondary renal damage are very rare complications of fungaluria.

- The preferred treatments of upper tract fungal infections are systemic and local antifungal administration, urinary drainage with percutaneous nephrostomy or ureteric stent and removal of foreign body.

renal damage. ${ }^{3}$ The preferred treatment of upper tract fungal infections is urinary drainage by a nephrostomy tube or ureteral catheter along with systemic and local antifungal administration and removal of foreign body. ${ }^{3}$ In the present case, an immunocompetent patient developed upper tract fungal infection (bezoar) as the forgotten DJ stent provided a nidus for fungal growth and proliferation.

Contributors AS and GG: concept, design, supervision, processing, writing of manuscript and critical analysis. DS: supervision, processing, writing of manuscript and critical analysis. MS: concept, supervision, writing of manuscript and critical analysis.

Funding The authors have not declared a specific grant for this research from any funding agency in the public, commercial or not-for-profit sectors.

Competing interests None declared.

Patient consent Obtained.

Provenance and peer review Not commissioned; externally peer reviewed.

\section{REFERENCES}

1 Irby PB, Stoller ML, McAninch JW. Fungal bezoars of the upper urinary tract. J Urol 1990;143:447-51.

2 Wainstein MA, Graham RC, Resnick MI. Predisposing factors of systemic fungal infections of the genitourinary tract. J Urol 1995;154:160-3.

3 Karpman E, Kurzrock EA, Low RK. Percutaneous nephroscopic removal of obstructing fungal bezoars and endopyelotomy in an infant. J Urol 2003;169:1499-500.

Copyright 2018 BMJ Publishing Group. All rights reserved. For permission to reuse any of this content visit

http://group.bmj.com/group/rights-licensing/permissions.

BMJ Case Report Fellows may re-use this article for personal use and teaching without any further permission.

Become a Fellow of BMJ Case Reports today and you can:

- Submit as many cases as you like

- Enjoy fast sympathetic peer review and rapid publication of accepted articles

- Access all the published articles

- Re-use any of the published material for personal use and teaching without further permission

For information on Institutional Fellowships contact consortiasales@bmjgroup.com

Visit casereports.bmj.com for more articles like this and to become a Fellow 